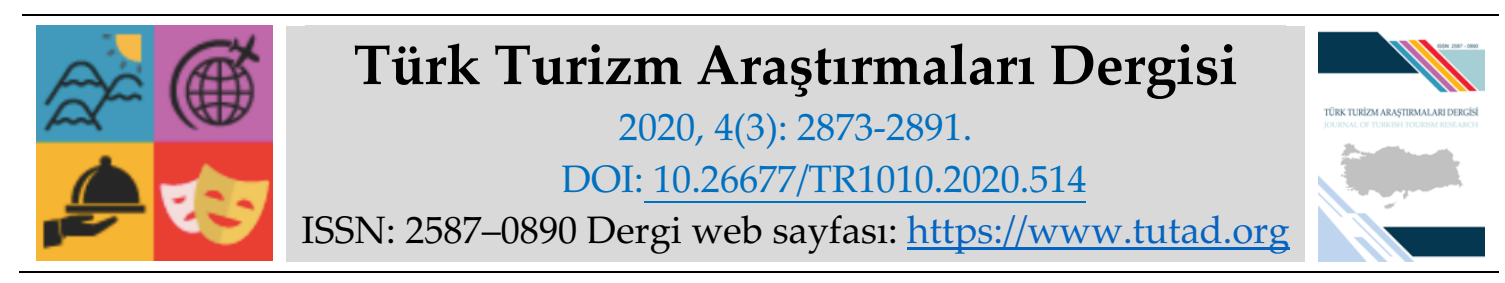

ARASTIRMA MAKALESI

\title{
Turizm İşletme Belgeli Otel İşletmelerinde İnovasyon Faaliyetleri: Sivas Örneği
}

Dr. Öğr. Üyesi Mustafa IŞKIN, Sivas Cumhuriyet Üniversitesi, Turizm Fakültesi, Sivas, e-posta: mustafaiskin@cumhuriyet.edu.tr

ORCID: https://orcid.org/0000-0002-5097-2268

Öz

Gerek konaklama bölümünde gerekse yiyecek içecek bölümünde yenilikler yaparak müşterilerin memnuniyetini sağlamak konaklama işletmeleri için önemlidir. Çünkü müşterilerin işletmeyi tekrar tercih etmeleri için müşterilere yenilikler sunmak gerekebilir. Konaklama işletmelerinin rekabet avantajı elde etmeleri ve varlıklarını sürdürebilmeleri için yenilikler ve geliştirme faaliyetleri kaçınılmaz bir olgudur. Bu araştırma Sivas'ta faaliyet gösteren turizm belgeli otel işletmelerinin yenilik faaliyetlerine bakışlarını ortaya koymak ve elde edilen verilerin analizi sonucunda ortaya çıkacak bilgiler ışı̆̆ında söz konusu işletmelere önerilerde bulunmak amacıyla yapılmıştır. Araştırmanın evrenini Sivas'ta faaliyet gösteren turizm belgeli oteller oluşturmaktadır. Araştırmada Hjalager (2002) tarafından oluşturulmuş olan inovasyon faaliyetlerine ilişkin model çerçevesinde oluşturulan ölçek kullanılmıştır. Çalışmada Sivas'ta faaliyet gösteren turizm belgeli otel işletmelerinin inovasyon faaliyetleri düzeylerine ilişkin analizler yapılmıştır. Araştırma sonucunda araştırma kapsamında bulunan otel işletmelerinin inovasyon faaliyetleri düzeylerinin, işletmenin yönetim şekline, çalışan sayısına, otel işletmelerinin yıldız sayısına ve inovasyon ile ilgili yönetici istihdamı durumuna göre farklılaştığ 1 tespit edilmiştir.

Anahtar Kelimeler: İnovasyon, Otel İşletmeleri, Sivas.

Makale Gönderme Tarihi: 14.05.2020

Makale Kabul Tarihi: 06.07.2020

\section{Önerilen Atıf:}

Işkın, M. (2020). Turizm İşletme Belgeli Otel İşletmelerinde İnovasyon Faaliyetleri: Sivas Örneği, Türk Turizm Araştırmaları Dergisi, 4(3): 2873-2891.

(C) 2020 Türk Turizm Araştırmaları Dergisi. 


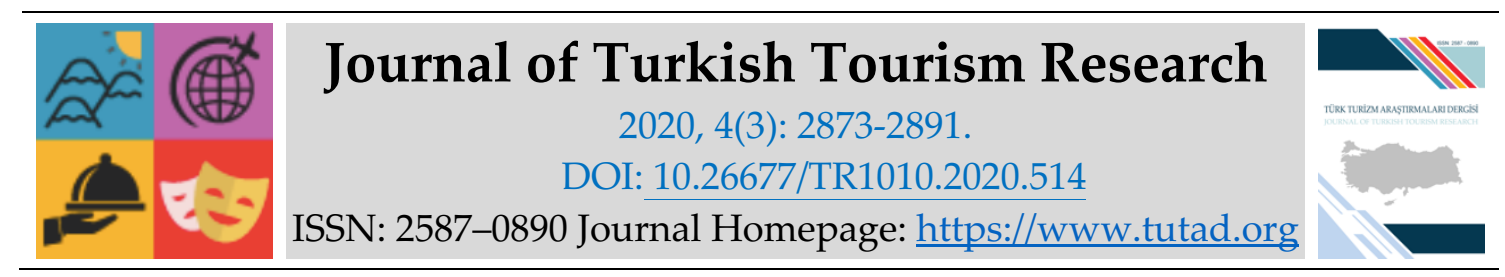

\title{
$\underline{\text { RESEARCH PAPER }}$
}

\section{Innovation Activities in Hotel Enterprises with Tourism Operation Certificate: The Case of Sivas}

Assistant Prof. Dr. Mustafa IŞKIN, Sivas Cumhuriyet University, Faculty of Tourism, Sivas, email: mustafaiskin@cumhuriyet.edu.tr ORCID: https://orcid.org/0000-0002-5097-2268

\begin{abstract}
Achieving customer satisfaction by innovating both in the accommodation section and in the food and beverage section is important for accommodation businesses. Because it may be necessary to present innovations to the customers so that they prefer the business again. Innovation and development activities are an inevitable phenomenon in order for accommodation companies to gain competitive advantage and sustain their existence. This research was carried out to reveal the views of the hotel companies with tourism investment and business certificates operating in Turkey to innovation activities and to make suggestions to these enterprises in the light of the information to be revealed as a result of the analysis of the data obtained. The universe of the research consists of hotels with tourism certificates operating in Sivas. In the research, the scale created within the framework of the model for innovation activities created by Hjalager (2002) was used. In the study, the analyzes of the innovation activities of the hotels with Tourism business certificates operating in Sivas were made. As a result of the research, it has been determined that the innovation activities levels of the hotel businesses differ according to the type of management of the business, the number of employees, the number of stars of the hotel enterprises and the employment status of the manager related to innovation.
\end{abstract}

Keywords: Innovation, Hotel Businesses, Sivas.

Received: 14.05 .2020

Accepted: 06.07.2020

\section{Suggested Citation:}

Işkın, M. (2020). Innovation Activities in Hotel Enterprises with Tourism Operation Certificate: The Case of Sivas, Journal of Turkish Tourism Research, 4(3): 2873-2891.

(C) 2020 Türk Turizm Araştırmaları Dergisi. 


\section{Gíriş}

Turizm sektöründe inovasyon, işletmeler açısından için kaçınılmaz bir olgu olarak kabul edilebilir. Çünkü günümüzde bilgi üretimi hızlı bir şekilde gerçekleşmektedir. Üretilen bilginin uygulamaya transferi en az bilgi üretimi kadar hızlı bir şekilde gerçekleşmektedir. İnovasyonların bir bölümü müşteri istek ve ihtiyaçları göz önünde bulundurularak yapılırken önemli bir bölümü ise müşterilerin istek ve ihtiyaçlarının dışında onların hayatını kolaylaştırmak için alanında uzman kişiler tarafından yapılmaktadır. Müşterilerin istek ve ihtiyaçlarının takip etmek ve onların istek ve ihtiyaçlarına cevap verecek yenilikleri yapmak işletmeler için önemlidir. Diğer taraftan daha değerli ve önemli olan inovasyon ise müşterilerin istek ve ihtiyaçlarının önüne geçerek onlara önemli kazanımlar sağlamak olarak görülebilir. Çünkü müşteriler söz konusu alanda uzman kişiler değillerdir. Yapılacak olan yenilikleri sadece müşterilerin inisiyatifine bırakmak makul bir yaklaşım olmayabilir.

Konaklama işletmeleri için inovasyonun önemi göz ardı edilemeyecek kadar önemlidir. Konaklama işletmelerinde müşteriler genellikle uzun süreli zaman geçirmektelerdir. Ayrıca müşteriler konaklama işletmelerinden memnun kalırlarsa genellikle söz konusu konaklama işletmesini tekrar tercih etmektelerdir (Bucak ve Özarslan, 2016: 25). Müşterilerin konaklama işletmelerinde uzun süre geçirmeleri ve memnuniyet sonrasında tekrar tercih etmeleri nedeniyle konaklama işletmelerinin kendilerini diğer işletmelerden ayıran önemli özelliklerini kaybetmeden inovasyonlar yapmaları gerekmektedir (Şimşek, 2019: 107). Çünkü müşteriler uzun süre geçirdikleri ve tekrar ziyaret ettikleri işletmelerde sürekli olarak aynı ürün, hizmet, mekân, uygulama, kullanılan teknoloji ve faaliyetlerle karşılaştıklarında müşteri memnuniyeti düzeyleri düşebilir (Hernandez-Perlines vd., 2019: 220). Bu nedenle konaklama işletmelerinin ürün, hizmet, mekân, uygulama, kullanılan teknoloji ve faaliyetlerinde inovasyonlar yapmaları işletmelerin rekabet avantaji elde etmeleri açısından önemlidir.

Birçok sektörde olduğu gibi turizm sektöründe de inovasyon önemli bir yere sahiptir. Turizm sektöründe birçok alanda yenilikler ortaya çıkmaktadır. Konaklama işletmeleri söz konusu yeniliklere ayak uydurmak zorunda kalmaktalardır. Bunun yanında konaklama işletmelerinin sektör genelindeki yeniliklerin yanında kendi özellerinde yenilikleri hayata geçirmeleri gerekmektedir (Divisekera ve Nguyen, 2018: 157). Ancak bu şekilde konaklama işletmeleri diğer işletmelerden farklılaşacak ve rekabet avantajı elde edebileceklerdir.

Yukarı belirtilen hususlardan dolayı bu çalışmada Sivas'ta faaliyet gösteren turizm işletme belgeli otellerin inovasyon faaliyetlerinin düzeyi tespit edilmeye çalışılmıştır. Çalışmada Sivas'ta faaliyet gösteren turizm işletme belgeli otellerin inovasyon yeteneklerine ilişkin durum tespiti yapılmaya çalışılmıştır. Ayrıca söz konusu otel işletmelerinin özelliklerine göre inovasyon faaliyetlerinin farklılaşıp farklılaşmadığının tespiti amaçlanmıştır. Böylelikle otel işletmelerinin yöneticilerinin inovasyon faaliyetleri açısından hangi düzeyde olduklarını görmeleri ve buna göre inovasyon faaliyetlerini şekillendirmeleri öngörülmüştür.

\section{KAVRAMSAL ÇERÇEVE}

Yenilik ve İnovasyon kavramları birbirleri ile ilinti kavramlardır. Ancak yenilik kavramı tam olarak inovasyon kavramını karşılamamaktadır. Türk Dil Kurumu sözlügüunde inovasyon "yenileşim" olarak ifade edilmektedir. Türk Dil Kurumu sözlügünnde Yenileşim ise “Değişen koşullara uyabilmek için toplumsal, kültürel ve yönetimsel ortamlarda yeni yöntemlerin kullanılmaya başlanması, yenilik, inovasyon" olarak ifade edilmiştir (https://sozluk.gov.tr/). Yenileşim ile ilgili verilen bu anlamda "yönetimsel ortamlarda yeni yöntemlerin kullanılmaya başlanması" ifadesi işletmecilik açısından önemlidir. Ancak bu ifade yine de inovasyon 
kavramını tam olarak açıklayamamaktadır. Bu tanımda inovasyonun karşılığı olarak verilen yenileşim kavramı işletmeler açısından ele alındığında sadece yönetimsel boyut ile sınırlandırılmıştır. Ancak inovasyonun yönetim alanı da dahil olmak üzere türleri bulunmaktadır. İnovasyonun türleri aşağıdaki şekilde sınıflandırılmıştır.

Tablo 1. İnovasyon Türleri

\begin{tabular}{|c|c|}
\hline \multirow{5}{*}{ İçeriğine göre İnovasyon Türleri } & Ürün veya Hizmet İnovasyonu \\
\hline & İş Modeli İnovasyonu \\
\hline & Pazarlama İnovasyonu \\
\hline & Süreç İnovasyonu \\
\hline & Deneyim İnovasyonu \\
\hline \multirow{2}{*}{$\begin{array}{l}\text { İçerdiği Değişimin Büyüklüğüne Göre } \\
\text { İnovasyon Türleri }\end{array}$} & Radikal İnovasyon \\
\hline & Artımlı İnovasyon \\
\hline \multirow{2}{*}{$\begin{array}{l}\text { Kapsadığı Etki Alanına Göre İnovasyon } \\
\text { Türleri }\end{array}$} & Toplumsal İnovasyon \\
\hline & Örgütsel İnovasyon \\
\hline
\end{tabular}

Kaynak: Ünal ve Kılınç, 2016:102; Kogabayev ve Maziliauskas, 2017: 64-69.

Tablo 1'de görüldüğü üzere inovasyon kavramı işletmeler açısından sadece yönetimsel boyut olarak ele alınamaz. Türk Dil Kurumu'nun tanımı inovasyonu açıklamakta tam anlamıyla yeterli değildir. İnovasyon ile ilgili konu üzerine çalışmış bilim insanları tarafından farklı şekillerde tanımlanmıştır. Söz konusu tanımlardan bazıları şu şekildedir;

-Schumpeter (1934) inovasyonu 5 (beş) farklı boyut ile tanımlamıştır. Schumpeter'e (1934) göre inovasyon; 1) tüketicilerin henüz tanımadıkları yeni bir ürün ya da hizmetin veya bir ürünün daha kaliteli ve işlevsel versiyonun piyasaya sürülmesi, 2) daha önce hiç kimse tarafından kullanılmamış veya test edilmemiş, bilimsel olarak yeni olduğu kabul görmüş, ticari olarak yeni bir şekilde üretimi ele alan, yeni üretim yöntemlerinin geliştirilmesi, 3) daha önce tamamına veya belirli bir parçasına girilmemiş yeni pazarlara açılmak, 4) yeni bir hammadde veya yarı mamul kaynağının keşfi veya elde edilmesi, 5) bir endüstri kolunda tekel oluşturabilecek organizasyonun oluşturulması şeklinde beş farklı boyutta kendini göstermektedir. İnovasyonun kapsamı açısından farklı boyutlarının olduğu Schumpeter (1934) tanımında açıkça görülmektedir.

-Drucker (1985) inovasyonu girişimcilik bağlamında tanımlamıştır. İnovasyonu girişimciliğin aracı olarak belirtmiştir. Drucker (1998) İnovasyonun, girişimcinin yüksek düzeyde mali getiri sağlayacak kaynaklar oluşturması, yüksek mali getiri sağlayacak potansiyele sahip veya mevcut durumda yüksek mali getiri sağlayan kaynakların desteklenmesi ve geliştirilmesi olduğunu belirtmiştir.

-Ekonomik İşbirliği ve Kalkınma Örgütü (OECD) (2019) inovasyon verilerinin toplanması ve yorumlanması için ilkelerin yer aldığı "Oslo Kılavuzu" adını verdiği bir kılavuz hazırlamıştır. Söz konusu kılavuz belirli aralıklarla yenilenmektedir. Bu kılavuzda işletmecilik alanında inovasyon, işletme tarafından kullanılan veya pazara sürülen, önceki ürünlerden veya iş 
süreçlerinden önemli derecede farklı olan, tamamıla yeni veya geliştirilmiş ürünler veya iş süreçleri olarak tanımlanmıştır (OECD, 2019).

Yukarıda verilen tanımlarda bazı noktalar ön plana çıkmaktadır. Ön plana çıkan söz konusu unsurlar, inovasyonun yeni ürün veya süreç içermesi, İnovasyon çerçevesinde geliştirilen ürün veya sürecin ticarileştirilmesi ve geliştirilen ürün veya hizmetin pazar ve sürecin kullanıcılar tarafından talep görmesidir. Söz konusu unsurlar doğrultusunda inovasyon, işletmelerin müşterilerin veya kullanıcıların talepte bulunmalarını beklemeden, ticari olarak kazanç sağlayacak, pazar ve kullanıcılar tarafından talep görecek, yeni ürünler, yeni süreçler geliştirmesi veya mevcut ürün ve süreçlerde köklü değişiklikler yapması olarak tanımlanabilir. Ancak konu ile ilgili çalışmalarda ürün veya hizmetlerde, işletme ve üretim süreçlerinde yapılan küçük çaplı olumlu değişimlerinde inovasyon olarak kabul edilebileceği belirtilmiştir (Rohtwell ve Gardiner, 1985: 168).

Yukarıda belirtilen tanımlarda yer alan unsurlar otel işletmeleri içinde geçerlidir. Otel işletmelerinin inovasyon faaliyetleri kapsamında ticari olarak karşılığı olan yeni ürün ve süreçler geliştirmeleri gerekmektedir. Aslında inovasyon faaliyetleri açısından otel işletmelerinin yerine getirmeleri gerekenler üretim işletmelerinden farklı değildir. Ancak otel işletmelerinin karakteristik özelliklerinden dolayı inovasyon faaliyetlerinin yerine getirilmesi zorlaşmaktadır.

Otel işletmelerinde inovasyon faaliyetlerinin gerçekleştirilmesinin önündeki bazı engeller bulunmaktadır. Otel işletmelerinin birçoğunun kurumsallaşma düzeylerinin düşük olması otel işletmelerinde yapılacak inovasyon faaliyetlerini olumsuz etkilemektedir. Ayrıca birçok otel işletmesinin ailelere ait olması, aile bireyleri tarafından yönetilmesi ve zincir oteller dişında kalan otellerin birçoğunun, küçük ölçekli olması otel işletmelerinde gerçekleştirilecek inovasyon faaliyetlerinin önünde önemli bir engel olarak görülebilir. Bu doğrultuda otel işletmelerinin küçük ölçekli olmalarına bağlı olarak ar-ge birimlerinin olmaması inovasyon faaliyetleri için uzman çalışan istihdamını engellemektedir. Dolayısıyla inovasyon faaliyetlerini sekteye uğratmaktadır. Turizm sektörü genelinde hakim olan otel işletmelerinde inovasyon faaliyetlerinin gerçekleştirilemeyeceğine ilişkin algıda otel işletmelerinin inovasyon faaliyetleri üzerinde olumsuz etki oluşturmaktadır. Ayrıca otel işletmelerinde gerçekleştirilen inovasyon faaliyetlerinin diğer işletmeler tarafından taklit edilmesinin kolay olması, taklit etmenin önünde engel bulunmaması ve otel işletmelerinin birbirleri arasında bilgi ve deneyim paylaşma konusunda ön yargılı olmaları buna bağlı olarak bilgi ve deneyimlerini saklamaları inovasyon faaliyetlerinin gerçekleştirilmesinin önünde engel olarak görülebilir (Hjalager, 2002; 469-470).

Yukarıda belirtilen nedenlerden dolayı otel işletmelerinde inovasyon fikrinin ortaya çıkması ve bu doğrultuda inovasyon faaliyetlerinin gerçekleştirilmesi ürün üreten işletmelere göre daha zor olmaktadır.

Hjalager (2002) yapmış olduğu çalışmada Abernathy ve Clark'in (1985) otomobil endüstrisi için yapmış olduğu inovasyon sınıflandırma modelini otel işletmelerine uyarlamıştır. Abernathy ve Clark'in (1985) modelinden hareketle Hjalager (2002) otel işletmelerinde gerçekleştirilebilecek inovasyon faaliyetlerinin sınıflandırıldığı bir model geliştirmiştir. Şekil 1'de otel işletmelerinde gerçekleştirilebilecek inovasyon faaliyetlerinin sınıflandırılması sonucu ortaya çıkan modele yer verilmiştir. Modelde temel olarak 4 temel inovasyon türü yer almaktadır; düzenli İnovasyonlar, niş inovasyonlar, radikal inovasyonlar, mimari inovasyonlar.

Şekil 1'de inovasyon türleri altında gerçekleştirilebilecek faaliyetlere yer verilmiştir. Otel işletmeleri her inovasyon türü altında farklı faaliyetleri gerçekleştirebilirler. Bu modelin oluşturulması inovasyon faaliyetlerinde otel işletmelerinin yöneticilerine yol göstermek açısından önemlidir. 


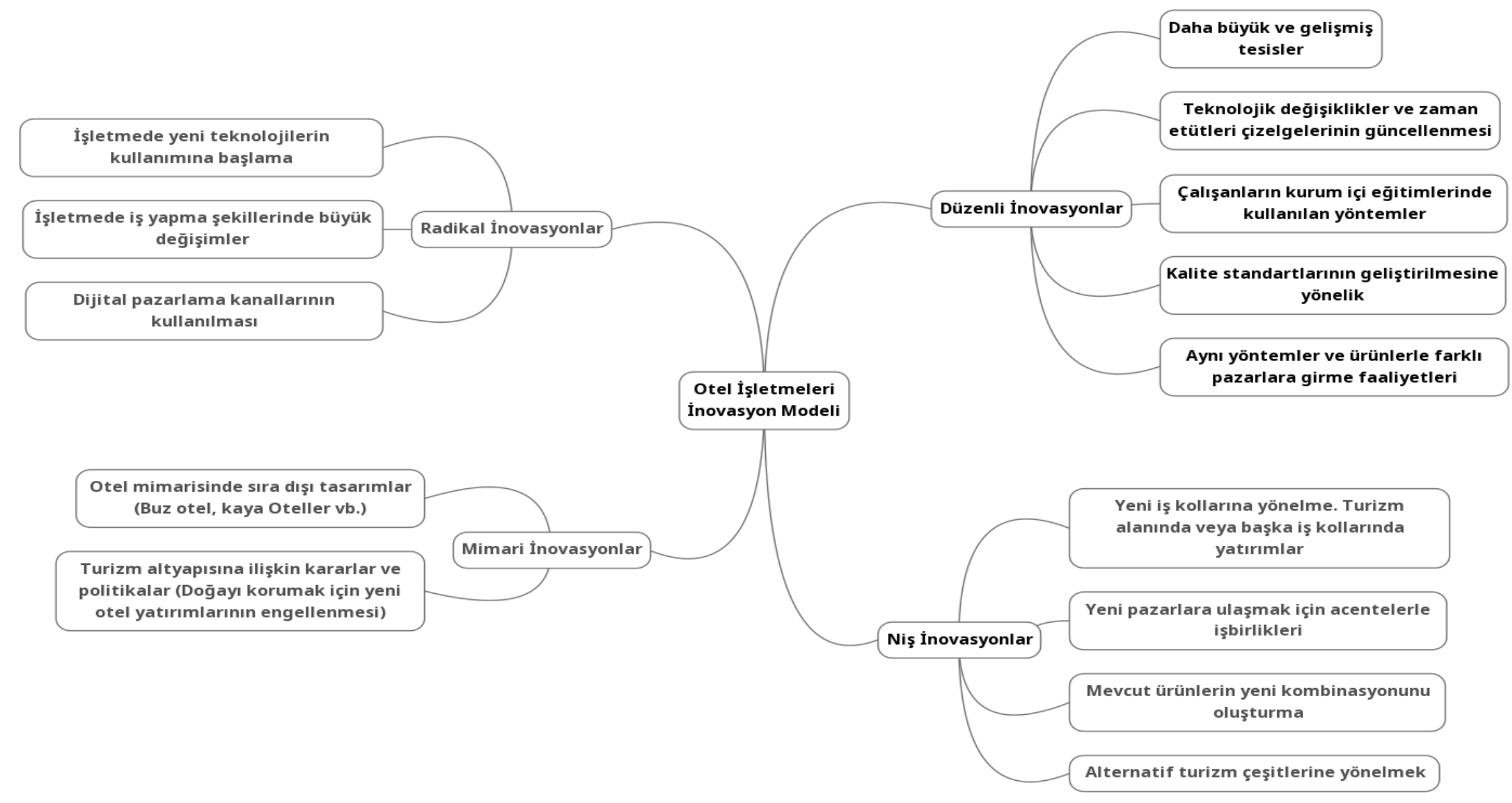

Şekil 1. Otel İşletmeleri İçin İnovasyon Modeli

Kaynak: Hjalager, 2002: 466-468. 
Şekil 1' de verilen inovasyon modelinde yer alan faaliyetler kapsamında yapılacak İnovasyonların gerçekleşebilmesi için işletmelerin sistematik olarak inovasyona yönelmeleri gerekmektedir. İnovasyon faaliyetlerinin işletmeler tarafından süreç olarak görülmesi ve bu sürecin iyi yönetilmesi inovasyon için ön şarttır.

Şekil 1'de verilen modelde yer alan inovasyon faaliyetlerinin gerçekleştirilmesi için inovasyon süreci takip edilmelidir. İnovasyon sürecinde, öncelikle yeni fikirlerin üretilmesi gerekir. Ancak fikir üretimi planlı ve sistematik olabileceği gibi işletme içerisinde veya dışarısında üretilen fikirlerin araştırılması yeni fikirlerin üretilmesi veya keşfedilmesi için önemlidir. Daha sonra üretilen veya keşfedilen fikirler doğrultusunda ürün veya hizmet konsepti geliştirme ve geliştirilen konsepti test edilmesi gerekir. Bu aşamadan sonra geliştirilen konsept kapsamındaki ürün veya hizmetler için pazarlama planı yapılması ve stratejilerin geliştirilmesi faaliyetleri gerçekleştirilmelidir. İnovasyon sürecinde bulunan veya geliştirilen ürün veya hizmetle ilgili iş analizlerinin (iş tanımları, iş gereklilikleri, iş değerleme vb.) yapılması işletmenin işleyişi açısından önemlidir. Yeni ürün veya hizmet doğrultusunda işletmenin ilgili süreçlerinin dizaynı sonrasında yeni ürün veya hizmet ortaya çıkar. Ortaya çıkan ürün veya hizmetin pazarda test edilir. Test edilen ürün veya hizmetin ticarileştirilmesi ve ilgili müşterilere sunulması inovasyon sürecinin son aşamasıdır (Kotler ve Kotler, 2016:121).

Otel işletmelerinin inovasyon faaliyetleri kapsamında yerine getirmeleri gereken süreç yukarıda belirtilmiştir. Ancak söz konusu sürecin gerçekleştirilmesi otel işletmelerinin inovasyon becerilerine sahip çalışanları bünyelerine çekmeleri veya inovasyon faaliyetlerinde dişardan destek almaları gerekir.

Otel işletmelerinde inovasyon faaliyetleri üzerine çeşitli akademik çalışmalar yapılmıştır. Söz konusu çalışmalardan bazılarına Tablo 2'de yer verilmiştir. Tablo 2' de görüldüğü üzere inovasyon faaliyetlerinin otel işletmeleri için önemli bir yeri vardır. Otel işletmelerinde inovasyon faaliyetlerinin hangi noktalarda ürün üreten işletmelerden farklılaştığı yöneticiler tarafından bilinmelidir. Bu doğrultuda inovasyon faaliyetlerine yön verilmelidir. Yukarıda yer alan çalışmalardan hareketle, otel işletmelerinin inovasyon faaliyetleri gerçekleştirmelerinin çeşitli zorluklara sahip olduğu söylenebilir. Otel işletmelerinin inovasyon konusunda yaşanan zorlukları aşmak için inovasyon faaliyetleri alanında bilgi ve birikime sahip kamu ve özel ar-ge kuruluşlarından destek almaları gerektiği söylenebilir. Yapılan çalışmalarda inovasyon faaliyetlerinin otel işletmelerinin performanslarını olumlu yönde etkilediği tespit edilmiştir. Bu nedenle otel işletmelerinin daha önce yapılmış çalışmalarda yer verilen önerileri dikkate alarak inovasyon faaliyetlerine odaklanmaları gerekir. Diğer taraftan yukarıda ki çalışmalarda görüldüğü üzere işletmelerin inovasyon performans düzeyleri söz konusu otel işletmelerinin yöneticilerinin inovasyon faaliyetlerine bakış açılarına göre farklılık göstermektedir. İnovasyon faaliyetlerinin gerçekleştirilmesi ve başarısı için yenilikçi yöneticilerin ve çalışanların istihdamı önemlidir. Otel işletmeleri yukarıda belirtilen unsurları göz önünde bulundurarak inovasyon faaliyetlerini gerçekleştirirlerse rekabet açısından avantaj elde edeceklerdir.

$\mathrm{Bu}$ çalışmada otel işletmelerinde inovasyon faaliyetleri ile ilgili teori ve daha önce yapılan çalışmalardan hareketle aşağıdaki hipotezler oluşturulmuştur (Hjalager, 2002; Orfila-Sintesb ve Jan Mattsson; Monteiro ve Sousa, 2011; Zengin ve Dursun, 2017);

Hı: Sivas'ta faaliyet gösteren turizm yatırım ve işletme belgeli otel işletmelerinin inovasyon faaliyetleri gerçekleştirme düzeyleri yüksektir.

$\mathbf{H}_{2}$ : Sivas'ta faaliyet gösteren yatırım ve işletme belgeli otel işletmelerinin inovasyon faaliyetleri düzeyleri işletmelerin özelliklerine göre farklılık göstermektedir. 
Tablo 2. Otel İşletmelerinde İnovasyon Faaliyetlerine İlişkin Yapılmış Bazı Çalışmalar

\begin{tabular}{|c|c|c|}
\hline Çalışmayı Yapan(lar) & Yili & Çalışmanın konusu \\
\hline Anne-Mette Hjalager & 2002 & $\begin{array}{l}\text { Çalışmada inovasyon kavramının otel işletmelerinde } \\
\text { kullanımına ilişkin değerlendirmeler yapılmıştır. Ayrıca } \\
\text { otel işletmeleri için inovasyon modeli önerilmiştir. } \\
\text { Çalışma sonucunda otel işletmelerinin inovasyon } \\
\text { faaliyetlerine tek başlarına odaklanmamaları, diğer } \\
\text { sektörlerden ve kamu kurumlarından destek almaları } \\
\text { gerektiği vurgulanmıstır. }\end{array}$ \\
\hline $\begin{array}{l}\text { Francina Orfila-Sintesb ve } \\
\text { Jan Mattsson }\end{array}$ & 2009 & $\begin{array}{l}\text { Çalışmada otel işletmelerinin inovasyon faaliyetlerini } \\
\text { kapsayan bir model geliştirilmiştir. Daha sonra söz } \\
\text { konusu model test edilmiştir. Model inovasyon faaliyetleri } \\
\text { için temel dört değişken yer almaktadır. Bu değişkenler; } \\
\text { yönetim, dış iletişim, hizmet kapsamı ve arka ofistir. } \\
\text { Çalışma sonucunda oluşturulan model kapsamında } \\
\text { gerçekleştirilen faaliyetlerin performansı olumlu etkileri } \\
\text { tespit edilmiştir. }\end{array}$ \\
\hline $\begin{array}{l}\text { Ileana Pardal Monteiro ve } \\
\text { Fernando Cardoso Sousa }\end{array}$ & 2011 & $\begin{array}{l}\text { Çalışmada inovasyonu teşvik eden ve yenilikçi olarak } \\
\text { kabul edilen işletmelerin yöneticilerin özellikleri } \\
\text { araştırılmıştır. Çalışmada yenilikçi özellikleri taşıyan ve } \\
\text { taşmayan yöneticilerin inovasyon faaliyetlerine ilişkin } \\
\text { algıları arasındaki farklılıklar tespit edilmeye çalışılmıştır. } \\
\text { Sonuç olarak yenilikçi olarak kabul edilen yöneticilerin } \\
\text { hizmet inovasyonu konusunda yenilikçi olmayan } \\
\text { yöneticilere göre olumlu yönde farklılaştıkları tespit } \\
\text { edilmiştir. }\end{array}$ \\
\hline $\begin{array}{l}\text { Burhanettin Zengin ve } \\
\text { Cihan Dursun }\end{array}$ & 2017 & $\begin{array}{l}\text { Çalışmada Doğu Marmara Bölgesinde faaliyet gösteren } 4 \\
\text { ve } 5 \text { yıldızlı otel işletmelerinin inovasyon faaliyetlerinin } \\
\text { rekabet avantajı üzerinde etkisi olup olmadığ tespit } \\
\text { edilmeye çalışılmıştır. Çalışmanın sonucunda inovasyon } \\
\text { faaliyetlerinin, otel işletmelerine rekabet avantajı sağladığ } 1 \\
\text { tespit edilmiştir. }\end{array}$ \\
\hline
\end{tabular}

\section{YÖNTEM}

Araştırmanın temel amacı Sivas'ta faaliyet gösteren turizm yatırım ve işletme belgeli otellerin inovasyon faaliyetleri düzeyi ve inovasyon faaliyetlerinin otellerin özelliklerine göre farklılaşıp farklılaşmadığını belirlemektir. Araştırmanın evrenini Sivas'ta faaliyet gösteren turizm yatırım ve işletme belgeli otellerin inovasyon faaliyetleri ile ilgili yöneticileri oluşturmaktadır. Çalışmada inovasyon faaliyetleri konusunda cevap alınabileceği düşünülen çalışanlara ulaşılmaya çalışıldığı için kasti (kararsal, güdümlü) (Karagöz, 2017: 66) örnekleme yöntemi kullanılmıştır. Araştırma kapsamındaki veriler 2019 Eylül ayı içerisinde toplanmıştır. Evren içerisinden ulaşılabilen örneklem sayısı 132'dir. Söz konusu örneklemin otellere göre dağılımı Tablo 3'te sunulmuştur. 
Tablo 3. Katılımcıların Görev Yaptıkları Otel İşletmeleri ve Örneklem Sayısı (N=132)

\begin{tabular}{|l|c|c|}
\hline Otelin Adı & Oda Sayısı & \multicolumn{2}{|c|}{ İnovasyon Faaliyetleri ile ilgili Çalışan Sayısı } \\
\hline Sivas Büyük Otel & 144 & 12 \\
\hline The Green Park & 148 & 16 \\
\hline Buruciye Otel & 46 & 12 \\
\hline Savona Otel & 53 & 14 \\
\hline Sivas Alaaddin Otel & 47 & \multicolumn{2}{|c|}{10} \\
\hline Behrampaşa Han Otel & 48 & 12 \\
\hline Köşk Otel & 66 & \multicolumn{2}{|c|}{14} \\
\hline Sultan Otel & 27 & \multicolumn{2}{|c|}{8} \\
\hline Nevv Otel & 33 & \multicolumn{2}{|c|}{8} \\
\hline Paşabey Otel & 36 & \multicolumn{2}{|c|}{10} \\
\hline Royal Sivas & 61 & \multicolumn{1}{|c|}{} \\
\hline Eretna Otel & 53 & \multicolumn{2}{|c|}{} \\
\hline
\end{tabular}

Belirlenen örneklemin tamamına ulaşılmıştır ve tamamına anket uygulanmıştır. Uygulanan ankette kullanılan inovasyon ölçeği Hjalager (2002) tarafından geliştirilen “Otel İnovasyon Modeli" temel alınarak geliştirilmiştir. Hjalager (2002) önerdiği modelden yola çıkılarak hazırlanan ölçekte yenilik faaliyetlerine ilişkin 19 adet ifade bulunmaktadır. Söz konusu 19 ifade toplamda dört alt değişkene yük taşımaktadır. İnovasyon faaliyetlerinin ölçümünde 5'li likert ölçeği kullanılmıştır. 5'li Likert ölçeğinde ifadelere katılım düzeyleri 1: Çok Az, 2:Az, 3: Orta Düzeyde 4:Fazla, 5:Çok olarak derecelendirilmiştir. Söz konusu ölçeğin geçerlilik ve güvenirliliğini ölçmek için ön uygulama yapılmıştır. Ön uygulama sürecinde konu ile ilgili uzmanların önerileri alınmış ve otel yöneticilerinin belirli kısmına geliştirilen ölçek uygulanmıştır. Çalışma kapsamında öncelikle güvenilirlik testi yapılmıştır. Güvenilirlik testinden sonra ölçeğe ilişkin faktör analizi, çalışmaya katılımcı sağlanan otellerin özelliklerine ilişkin frekans analizi ve normallik testleri, sonrasında değişken gruplarının sayısına uygun olarak Mann-Whitney U, Kruskal-Wallis ve Jonckheere-Terpstra Siralı Alternatifler testi analizleri uygulanmıştır (Karagöz, 2017: 271; Can, 2019: 88-320).

\section{ANALIZ ve BULGULAR}

Kullanılan ölçeğin güvenilirlik düzeyini belirlemek için yapılan güvenilirlik analizi sonucunda 19 maddeden oluşan otel işletmelerinde inovasyon faaliyetleri ölçeğinin Cronbach Alpha katsayısı 0,935 olarak tespit edilmiştir. Güvenilirlik testi sonucuna göre ölçeğin yüksek derecede güvenilirlik sağladığı söylenebilir (Büyüköztürk, 2010:168).

Oluşturulan ölçeğin inovasyon faaliyetlerini ölçme derecesini belirlemek için ölçeği oluşturan 19 ifadeyi kapsayan açıklayıcı faktör analizi uygulanmıştır. Ölçekte yer alan ifadelerin ölçülmek istenen alt değişkenlere 0,50 üzerinde yük taşıdığ 1 tespit edilmiştir. Bu nedenle ölçekten madde çıkarılmamıştır. Ayrıca yapılan faktör analizi sonucunda KMO katsayısı 0,826 p(sig.) $=0,000$ 
olarak tespit edilmiştir. Bu durum ölçeğin ve örneklemin yeterli olduğunu göstermektedir (Karagöz, 2017: 408).

Araştırma kapsamında ulaşılan, anket uygulanan ve veri elde edilen otellere ilişkin özelliklere çalışmanın bu kısmında yer verilmiştir. Söz konusu işletmelere ilişkin araştırma kapsamında yer alan özellikler Tablo 4'te verilmiştir.

Tablo 4. Katılımcıların Görev Yaptıkları Otellerin Özelliklerine İlişkin Frekans Analizleri (N=132)

\begin{tabular}{|c|c|c|c|c|c|}
\hline Otelin Hizmet Süresi & $\mathbf{N}$ & $\%$ & İnovasyon ile İlgili Yönetici & $\mathbf{N}$ & $\%$ \\
\hline 1 yıl ve altı & 4 & 3,0 & Var & 30 & 22,7 \\
\hline $2-4$ yıl & 14 & 10,6 & Yok & 102 & 77,3 \\
\hline $5-7$ yil & 28 & 21,2 & Toplam & 132 & 100,0 \\
\hline $8-10$ yıl & 22 & 16.7 & $\begin{array}{l}\text { Son } 5 \text { Yildaki Otel Tarafından } \\
\text { Geliştirilen Ürün/Hizmet Sayısı }\end{array}$ & $\mathbf{N}$ & $\%$ \\
\hline 10 yıl ve üzeri & 64 & 45,5 & 0 & 88 & 66,7 \\
\hline Toplam & 132 & 100,0 & 1 & 10 & 7,6 \\
\hline Otelin Çalışan Sayısı & $\mathbf{N}$ & $\%$ & 2 & 8 & 6,1 \\
\hline 10 ve alt & 22 & 16,7 & 3 & 6 & 4,5 \\
\hline $11-20$ & 52 & 39,4 & 4 & 14 & 10,6 \\
\hline $21-30$ & 32 & 24,2 & 5 ve üzeri & 6 & 4,5 \\
\hline $31-40$ & 12 & 9,1 & Toplam & 132 & 100,0 \\
\hline $41-50$ & 4 & 3,0 & Otelin Yıldız Sayısı & & \\
\hline 51 ve üzeri & 10 & 7,6 & 3 Yildız & 66 & 50,0 \\
\hline Toplam & 132 & 100,0 & 4 Yıldız & 66 & 50,0 \\
\hline $\begin{array}{l}\text { Otellerin Yönetim Açısından } \\
\text { Sinuflandırılması }\end{array}$ & $\mathbf{N}$ & $\%$ & Toplam & 132 & 100,0 \\
\hline Şahıs Otel İşletmesi & 114 & 86,4 & & & \\
\hline Grup Otel İşletmesi & 18 & 13,6 & & & \\
\hline Toplam & 132 & 100,0 & & & \\
\hline
\end{tabular}

Tablo 4'te araştırmaya katılan yöneticilerin görev yaptıkları otellere ilişkin frekans analizi sonuçları verilmiştir. Analiz sonuçlarına göre katılımcı yöneticilerin görev yaptıkları otellerin $\% 45$, 5'i 10 yıl ve üzeri süredir hizmet vermektelerdir. Diğer taraftan çalışan sayısı açısından değerlendirme yapıldığında, 11-20 ve 21-30 çalışan sayısına sahip otellerin tüm otellerin 73,6'sını oluşturduğu tespit edilmiştir. Otellerin yönetim tarzlarına bakıldığında büyük bir kısmının, sayısal olarak \%86,4'ünün şahıs işletmesi olduğu belirlenmiştir. Otel işletmelerinde inovasyon ile ilgili yönetici olup olmadığına ilişkin frekans analizi sonucunda söz konusu otellerin \%77,3'ünde inovasyon ile ilgili yönetici bulunmadığı tespit edilmiştir. Ayrıca araştırma kapsamındaki otellerin $\% 66,7^{\prime} \operatorname{sinin}$ son bir yıl içerisinde yeni bir ürün veya hizmet geliştirmediği tespit 
edilmiştir. Araştırma kapsamındaki otellerin \%50'sinin 3 yıldızlı, \%50'sinin ise 4 yıldızlı olduğu belirlenmiştir.

Araştırma kapsamında oluşturulan hipotezlerden;

"Sivas'ta faaliyet gösteren turizm yatırım ve işletme belgeli otel işletmelerinin inovasyon faaliyetleri gerçekleştirme düzeyleri yüksektir"

Hipotezinin test edilmesi için öncelikler ifadelerin ortalamaları alınarak alt değişkenler oluşturulmuştur. Oluşturulan alt değişkenlerinde ortalaması alınmış ve "inovasyon faaliyetleri" ana değişkeni oluşturulmuştur. İnovasyon faaliyetleri ana değişkenine ilişkin ortalama 3,08 olarak tespit edilmiştir. Sivas'ta faaliyet gösteren otel işletmelerinin inovasyon faaliyetlerine ilişkin ortalamaya göre söz konusu otel işletmelerinin inovasyon faaliyetleri düzeylerinin orta düzeyde olduğu tespit edilmiştir. Bu nedenle "Sivas'ta faaliyet gösteren turizm yatırım ve işletme belgeli otel işletmelerinin inovasyon faaliyetleri gerçekleştirme düzeyleri yüksektir" hipotezi ret edilmiştir.

Araştırma kapsamında toplanan verilerin normal dağılım gösterip göstermediğine ilişkin yapılan analizlerin sonuçları Tablo 5'te sunulmuştur.

Tablo 5. Normallik Testi

\begin{tabular}{|l|c|c|c|c|c|c|}
\hline \multirow{2}{*}{} & \multicolumn{3}{|c|}{ Kolmogorov-Smirnov $^{\mathrm{a}}$} & \multicolumn{3}{c|}{ Shapiro-Wilk } \\
\cline { 2 - 7 } & Statistic & $\mathrm{df}$ & Sig. & Statistic & $\mathrm{df}$ & Sig. \\
\hline İnovasyon Faaliyetleri &, 219 & 262 &, 000 &, 870 & 262 &, 000 \\
\hline Radikal İnovasyon &, 140 & 262 &, 000 &, 907 & 262 &, 000 \\
\hline Niş İnovasyon &, 140 & 262 &, 000 &, 946 & 262 &, 000 \\
\hline Mimari İnovasyon &, 156 & 262 &, 000 &, 946 & 262 &, 000 \\
\hline Düzenli İnovasyonlar &, 170 & 262 &, 000 &, 905 & 262 &, 000 \\
\hline
\end{tabular}

Tablo 5 'te görüldügü üzere otel işletmelerinde gerçekleştirilebilecek inovasyon faaliyetlerinin uygulanma düzeylerini ölçmek için kullanılan ölçeğin tamamından ve alt değişken düzeyinde elde edilen verilerin normal dağılım göstermediği tespit edilmiştir. Verilerin normal dağılım gösterip göstermediğini tespit etmek için kullanılan Kolmogorov-Simirnov testine ilişkin tabloda "Sig." olarak gösterilen $\mathrm{p}$ değerinin 0,05 'ten küçük olması elde edilen verilerin normal dağılımdan farklı olduğunu göstermektedir.

Araştırmada elde edilen veriler normal dağılım göstermediği için iki grup arasındaki farklılıkları tespit etmek için Mann-Whitney $U$ ve ikiden fazla gruplar arasındaki farklılıkları tespit etmek için ise Kruskal-Wallis testi uygulanmıştır.

Tablo $6^{\prime}$ da görüldüğü üzere araştırma kapsamında olan ve şahıslar tarafından yönetilen otel işletmeleri ile gruplar (zincir) tarafından yönetilen otel işletmelerinin inovasyon faaliyetleri düzeyleri arasında farklılık bulunmaktadır $(\mathrm{U}=312.000, \mathrm{p}<0,05)$. Hesaplanan sıralı ortalama değerlerine bakıldığında, araştırma kapsamında ki grup otel işletmelerinin inovasyon faaliyetleri düzeylerinin $(106,17)$, şahıs otel işletmelerinin inovasyon faaliyeti düzeylerinden $(60,24)$ anlamlı düzeyde fazla olduğu görülmektedir. Bu durumda araştırma kapsamında ki şahıs oteli 
işletmeleri ve grup oteli işletmelerinin inovasyon faaliyetlerinin birbirinden farklı olduğu söylenebilir. Bu sonuç literatür ve daha önce konu ile ilgili yapılan çalışmalar incelendiğinde beklenilen bir sonuçtur (Karacaoğlu ve Sözbilen, 2013: 41; Özkoç ve Kemer, 2018: 568: Kallmuenzer, 2018: 1978). Çünkü şahıs otelleri genellikle aile bireyleri tarafından yönetilmektelerdir. $\mathrm{Bu}$ nedenle kurumsallaşma düzeyleri düşük düzeyde olmaktadır. Kurumsallaşma düzeyinin düşük olması inovasyon faaliyetlerinin yürütülmesini engelleyebilir. Ayrıca grup otelleri genellikle büyük ölçekli işletmelerdir. Bu nedenle inovasyon faaliyetleri için yeterli insan ve finans kaynaklarına sahip olabilmektelerdir.

Tablo 6. Katılımcıların Sağlandığı Otellerin Yönetim Şekli, İnovasyon Yönetici Olup Olmaması ve Yıldız Sayılarına Göre İnovasyon Faaliyetleri Düzeylerinin Farklılığını Gösterir MannWhitney U Testi Tablosu

\begin{tabular}{|c|c|c|c|c|}
\hline Grup & $\mathbf{N}$ & $\begin{array}{c}\text { Siralı } \\
\text { Ortalama }\end{array}$ & $\begin{array}{l}\text { Mann-Whitney } \\
\text { U Değeri }\end{array}$ & $\begin{array}{c}\text { Asymp. Sig. (2- } \\
\text { tailed) } \\
\text { p }\end{array}$ \\
\hline $\begin{array}{l}\text { Şahıs İşletmesi } \\
\text { Grup İşletmesi }\end{array}$ & $\begin{array}{c}114 \\
18\end{array}$ & $\begin{array}{r}60,24 \\
106,17\end{array}$ & 312,000 & 000 \\
\hline $\begin{array}{l}3 \text { Yildız } \\
4 \text { Yildız }\end{array}$ & $\begin{array}{l}66 \\
66\end{array}$ & $\begin{array}{l}44,17 \\
88,83\end{array}$ & 704,000 & 000 \\
\hline $\begin{array}{l}\text { Yönetici Yok } \\
\text { Yönetici Var }\end{array}$ & $\begin{array}{c}102 \\
30\end{array}$ & $\begin{array}{r}52,75 \\
113,23\end{array}$ & 128,000 & 000 \\
\hline
\end{tabular}

Diğer taraftan araştırma kapsamındaki otellerin yıldız sayılarına göre inovasyon faaliyetleri düzeylerinin farklılaşıp farklılaşmadığına bakıldığında, söz konusu otellerin inovasyon faaliyetleri düzeylerinin yıldız sayılarına göre farklılaştığı tespit edilmiştir ( $U=704,000, p<0,05)$. Hesaplanan sıralı ortalama değerlerine bakıldığında, araştırma kapsamındaki 4 yıldızlı otel işletmelerinin inovasyon faaliyetleri düzeylerinin $(88,83)$, araştırma kapsamındaki 3 yıldızlı otellerin inovasyon faaliyetleri düzeylerinden $(44,17)$ anlamlı düzeyde daha fazla olduğu görülmektedir. Bu durumda araştırma kapsamında yer alan 4 yıldızlı otel işletmeleri ve 3 yıldızlı otel işletmeleri arasında inovasyon faaliyetleri açısından farklılık olduğu söylenebilir. Literatür incelendiğinde benzer çalışmalarda, otel işletmelerinin yıldız sayısı arttıkça inovasyon faaliyetleri düzeylerinde arttığına ilişkin araştırma sonuçlarına ulaşılmıştır (Pardo vd., 2013: 1-2; Namjooyan, 2015: 53-54). Otel işletmelerinin yıldız sayılarının artması, otel işletmelerinin ölçek olarak büyümeleri olarak kabul edilebilir. Çünkü turizm işletmelerinin yasal sınıflandırmasına ilişkin yönetmelikte, yıldız sayısına göre oda sayısı kriteri bulunmaktadır. Bu nedenle daha fazla yıldıza sahip otellerin inovasyon için ayırabilecekleri mali kaynaklar daha fazla olabilir. Ayrıca oda sayısına bağlı olarak çalışan sayısı artacağı için yıldız sayısı yüksek otel işletmelerinde inovasyon faaliyetleri ile ilgili personel istihdamı gerçekleştirmek daha kolay olabilir.

Araştırma kapsamındaki otel işletmelerinin bünyesinde inovasyon ile ilgili yönetici bulundurma durumlarına göre inovasyon faaliyetleri düzeylerinin farklılaşıp farklılaşmadığına bakıldığında, söz konusu otel işletmelerinin inovasyon faaliyetlerinin inovasyon ile ilgili yönetici bulundurma durumlarına göre farklılaştı̆̆ tespit edilmiştir $(U=128,000, p<0,05)$. Hesaplanan sıralı ortalama 
değerlerine göre, araştırma kapsamında yer alan otel işletmelerinden inovasyon ile ilgili yönetici bulunduranların inovasyon faaliyet düzeylerinin $(113,23)$, inovasyon ile ilgili yönetici bulundurmayan $(52,75)$ otel işletmelerinden anlamlı düzeyde daha fazla olduğu tespit edilmiştir. $\mathrm{Bu}$ durumda araştırma kapsamında yer alan otel işletmelerinin inovasyon faaliyetleri düzeylerinin inovasyon ile ilgili yönetici bulundurup bulundurmama durumuna göre farklılık gösterdiği söylenebilir. Literatür ve konu ile ilgili daha önce yapılmış çalışmalar araştırma sonuçlarını desteklemektedir (Crossan ve Apaydin, 2010: 1179; Abdi vd., 2015: 153). İnovasyon faaliyetleri ile ilgili yönetici istihdamı, otel işletmelerinin inovasyon faaliyetlerini doğrudan etkilemektedir. Çünkü inovasyon ile ilgili inovasyon ile ilgili yöneticiler tarafından süreçlerin tasarımı, çalışanların inovasyon ile ilgili bilgilendirilmeleri ve yönlendirilmeleri gerekmektedir. Söz konusu faaliyetlerin başarısı için inovasyon ile ilgili yönetici bulunması önemli bir etkiye sahiptir (Crossan ve Apaydin, 2010: 1179).

Tablo 7. Katılımcıların Sağlandığı Otellerin Faaliyet Süreleri, Çalışan Sayıları ve Otel Tarafında Son 5 Yıl İçerisinde Geliştirilen Ürün/Hizmet Sayılarına Göre İnovasyon Faaliyeti Düzeylerinin Farklılı̆̆ını Gösterir Kruskal-Wallis ve Jonckheere-Terpstra Sıralı Alternatifler Testleri Tablosu

\begin{tabular}{|c|c|c|c|c|c|c|c|c|}
\hline & Grup & $\mathbf{N}$ & Siralı & Krusk & $1-W$ & llis & $\begin{array}{r}\text { Jonckh } \\
\text { Terps }\end{array}$ & \\
\hline & & & & $X^{2}$ & df & p & Medyan & p \\
\hline & 1 yıl ve altı & 4 & 66,50 & & & & 3,0000 & \\
\hline & 2-4 yıl & 14 & 42,50 & & & & 2,0000 & \\
\hline Hizmet Süresi & $5-7$ yıl & 28 & 89,21 & 18,213 & 4 & ,001 & 4,0000 & ,324 \\
\hline & 8-10 yıl & 22 & 68,68 & & & & 3,0000 & \\
\hline & 10 yıl ve üzeri & 64 & 61,06 & & & & 2,5000 & \\
\hline & 10 ve alt1 & 22 & 26,23 & & & & 2,0000 & \\
\hline & $11-20$ & 52 & 56,54 & & & & 3,0000 & \\
\hline & $21-30$ & 32 & 79,63 & $(0011$ & 5 & 000 & 3,0000 & 000 \\
\hline Ģallşan Sayisi & $31-40$ & 12 & 96,50 & 64,011 & 3 & (2) & 4,0000 & - \\
\hline & $41-50$ & 4 & 125,50 & & & & 5,0000 & \\
\hline & 50 ve üzeri & 10 & 105,30 & & & & 5,0000 & \\
\hline & 0 & 88 & 51,23 & & & & 2,5000 & \\
\hline & 1 & 10 & 66,50 & & & & 3,0000 & \\
\hline Geliştirilen & 2 & 8 & 102,50 & & & & 4,0000 & \\
\hline $\begin{array}{c}\text { Urün/Hizmet } \\
\text { Savısı }\end{array}$ & 3 & 6 & 125,50 & 57,261 & 5 & 000 & 5,0000 & ,000 \\
\hline & 4 & 14 & 97,93 & & & & 4,0000 & \\
\hline & 5 ve üzeri & 6 & 110,17 & & & & 4,0000 & \\
\hline
\end{tabular}


Elde edilen bulgulara göre araştırma kapsamındaki otel işletmelerinin inovasyon faaliyetleri düzeylerinin hizmet sürelerine göre farklılaştığı tespit edilmiştir $(p<0,05)$. Ancak JonckheereTerpstra testi analizi sonucunda en az bir ana kütle ortalamasının, diğer ana kütle ortalamalarından küçük olmadığı tespit edilmiştir $(\mathrm{p}=0,324)$. Ancak ikili gruplar seçilerek yapılan Mann-Whitney U testi sonucunda 2-4 yıl ve 5-7 yıl arasında hizmet veren otel işletmeleri arasında inovasyon faaliyetleri düzeyleri bakımından anlamlı farklılık olduğu tespit edilmiştir. Sıralı ortalamalara bakıldığında 2-4 yıl hizmet süresi olan otel işletmelerinin inovasyon faaliyetleri düzeylerinin (42,50), 5-7 yıl hizmet süresi olan işletmelerin inovasyon faaliyetleri düzeylerinden $(89,21)$ daha az olduğu görülmektedir. Daha önce yapılmış çalışmaların sonuçları, araştırma sonucunda ulaşılan sonuçları desteklemektedir (Kılıç ve Keklik, 2012: 93). Otel işletmelerinin hizmet sürelerinin inovasyon faaliyetleri açısından iki yönlü role sahiptir denilebilir. İlk olarak otel işletmelerinin hizmet sürelerinin fazla olması, işletmelere tecrübe, bilgi birikimi, müşteriyi daha iyi tanıma ve çevreyi tanıma gibi önemli avantajlar sağlayabilir. Ancak diğer taraftan işletme bu avantajları iyi kullanamaz, çevreyi takip edip analizler yapamaz ve kendini güncel tutamaz ise hizmet süresi önemli bir dezavantaja dönüşebilir. Araştırmada görüldügüü üzere hizmet süresi 5-7 yıl olan işletmelerin inovasyon faaliyetlerinin daha yüksektir. Bunun nedeni olarak daha fazla hizmet süresine sahip işletmelerin çevre analizi konusunda yetersiz kalmaları gösterilebilir.

Araştırma kapsamında yer alan otel işletmelerinin inovasyon faaliyetleri düzeylerinin söz konusu otel işletmelerinin çalışan sayılarına göre farklılaşıp farklılaşmadığına ilişkin analizler sonucunda, araştırma kapsamında yer alan otel işletmelerinin inovasyon faaliyetlerinin çalışan sayılarına göre farklılaştığ 1 tespit edilmiştir $(\mathrm{p}<0,05)$. Jonckheere-Terpstra testi sonucunda en az bir ana kütle ortalamasının, diğer ana kütle ortalamalarından küçük olduğu tespit edilmiştir $(p=0,000)$. Analiz sonuçlarına göre çalışan sayısı çok olan işletmelerin inovasyon faaliyetleri düzeyleri yüksektir. Literatür ve daha önce yapılan çalışmalar incelendiğinde, işletmelerin çalışan sayısı ve büyüklüğü ile inovasyon faaliyetleri arasında ilişki olduğu ve işletmelerin çalışan sayılarının inovasyon faaliyetlerini pozitif yönlü etkilediği görülmüştür (Akın ve Reyhanoğlu, 2014: 23). Otel işletmelerinin çalışan sayısının fazla olması, inovasyon faaliyetleri için daha fazla çalışan görevlendirmeye imkân tanıyabilir. Ayrıca otel işletmesi bünyesinde daha fazla çalışanın bulunması farklı bakış açısına sahip çalışan sayısını artırabilir. Bu nedenle farklı fikirlerin ortaya çıkma olasılığı artabilir. Bu yüzden çalışan sayısının fazla olması inovasyon faaliyetleri için önemlidir.

Sivas'ta faaliyet gösteren turizm işletme belgeli otel işletmelerinin inovasyon faaliyetleri düzeylerinin son 1 yıl içerisinde geliştirdikleri ürün veya hizmet sayısına göre farklılaşıp farklılaşmadığını belirlemek için yapılan analiz sonucunda, söz konusu otel işletmelerinin inovasyon faaliyetlerinin son 1 yıl içerisinde geliştirilen ürün veya hizmet sayısına göre farklılaştığ 1 tespit edilmiştir $(\mathrm{p}<0,05)$. Jonckheere-Terpstra testi sonucunda en az bir ana kütle ortalamasının, diğer ana kütle ortalamalarından küçük olduğu tespit edilmiştir $(\mathrm{p}=0,000)$. Analiz sonuçlarına göre, son 1 yıl içerisinde 3 ürün veya hizmet geliştiren otel işletmelerinin en yüksek inovasyon faaliyeti düzeyine sahip olduğu tespit edilmiştir. Otel işletmeleri tarafından son bir yıl içerisinde geliştirilen yeni ürün veya hizmet sayısı, inovasyon faaliyetlerinin çıtısı olarak kabul edilebilir. Bu nedenle inovasyon faaliyetlerinin son bir yıl içerisinde geliştirilen ürün veya hizmet sayısına göre farklılaşması beklenen bir sonuçtur.

Yapılan analizler sonucunda Sivas'ta faaliyet gösteren turizm işletme belgeli otellerin inovasyon faaliyetlerinin, teorik olarak farklılık göstermesine neden olabilecek işletme özelliklerine göre farklılaşma gösterdiği tespit edilmiştir. Bu durumda, "Sivas'ta faaliyet gösteren yatırım ve işletme belgeli otel işletmelerinin inovasyon faaliyetleri düzeyleri işletmelerin özelliklerine göre farklılık göstermektedir" hipotezi kabul edilmiştir. 


\section{SONUÇ ve ÖNERILER}

Yapılan analizler sonucunda Sivas'ta faaliyet gösteren turizm işletme belgeli otel işletmelerine ilişkin dikkat çekici sonuçlar elde edilmiştir. Söz konusu sonuçlar şu şekildedir. Söz konusu otel işletmelerinin \%45,5'inin 10 yıl veya daha üzerinde hizmet süresine sahip olmalarıdır. Bu sonuç aslında Sivas'ta faaliyet gösteren turizm işletme belgeli otellerin deneyimli oteller olduklarını göstermektedir. Ancak diğer taraftan otel işletmelerinin yarısına yakınının tecrübeli olması inovasyon faaliyetlerinin düzeyini düşürmektedir şeklinde yorum yapılabilir. Çünkü hizmet süresi 10 yıl ver üzeri olan otel işletmelerinin inovasyon faaliyetleri düzeyleri hizmet yılı 5-7 yıl, 8-10 yıl ve 1 yıl ve altı olan işletmelerden daha düşüktür. Bunun nedeni otel işletmelerinin kendilerini yenilikleri takip etme konusunda güncelleyememeleri olabilir. Ayrıca işletmelerin inovasyon için müşteri istek ve taleplerini takip etmelerinden öteye geçmeleri ve müşterilerin istek ve taleplerini yönlendirebilme kabiliyetini elde etmeleri gerekir. Bunun için işletmenin dinamik ve güncel yapıya sahip olması gerekir (Jones, 2017:384). Daha önce konu ile ilgili yapılan çalışmalara bakıldığında, işletmenin hizmet süresi ile inovasyon faaliyetleri arasında anlamlı bir ilişki veya farklılık bulunamamıştır (Tekin ve Durna, 2012; Çetin ve Gedik, 2017). Daha önce yapılan çalışmaların sonuçları bu çalışmayı desteklemese de işletmelerin hizmet sürelerine göre inovasyon faaliyetlerinin farklılık göstermesi literatürde beklenen bir durumdur.

Diğer taraftan araştırma kapsamında yer alan otel işletmelerinin çalışan sayılarına göre inovasyon faaliyetleri düzeylerinin farklılık gösterdiği belirlenmiştir. Hjalager (2002) çalışmasında küçük işletmelerin inovasyon faaliyetleri için çalışan görevlendiremediğini ve bu nedenle küçük otel işletmelerinin inovasyon faaliyetlerinin yetersiz olduğunu belirtmiştir. Araştırma bu görüşü desteklemektedir. Bu sonuç üzerine değerlendirme yapıldığında daha fazla çalışan olan otel işletmelerinde inovasyon ile ilgili birimlerin kurulması veya inovasyon ile ilgili çalışan görevlendirilmesi daha kolay olabilir. Az çalışanı olan otel işletmelerinin inovasyon faaliyetleri düzeylerinin düşük olması bu duruma bağlanabilir.

Araştırma kapsamında ki otel işletmelerinin \%51,23'ünün son 1 yıl içerisinde hiç ürün veya hizmet geliştirememiş olması dikkat çekicidir. Söz konusu otel işletmelerinde inovasyon faaliyetlerinin son 1 yıl içerisinde geliştirilen ürün veya hizmet sayısına göre farklılaşıp farklılaşmadığı ile ilgili analizler sonucunda, yıl içerisinde 3 ürün veya hizmet geliştiren otel işletmelerinin inovasyon faaliyetleri düzeylerinin yüksek olması dikkat çekicidir. Burada yıl içerisinde 5 ve üzeri ürün veya hizmet geliştiren otel işletmelerinin inovasyon faaliyetleri düzeylerinin yüksek olması beklenirken 3 olan işletmelerin inovasyon faaliyetleri daha yüksek çıkmıştır. Bu durum inovasyon faaliyetlerinin düzenli olarak yürütülmesine bağlı olabilir. Bazı işletmelerde inovasyon faaliyetleri kurum kültürünün parçası haline getirilmektedir. Bazı işletmeler ise belirli dönemlerde inovasyon faaliyetlerine ağırlık vermekte ve inovasyon faaliyetleri dönemsel olarak yürütülmektedir. Bu nedenle böyle bir sonuç ortaya çıkmış olabilir.

Araştırma sonuçlarına bakıldığında, araştırma kapsamındaki grup otel işletmelerinin inovasyon faaliyetleri düzeylerinin şahıs otel işletmelerinin inovasyon faaliyetleri düzeyinden önemli derecede yüksek olduğu tespit edilmiştir. Bu sonuç literatür ve daha önce yapılan çalışmalarca desteklenmektedir. Bunun nedeni olarak grup otel işletmelerinin daha kurumsal bir yapıda faaliyet göstermeleri ve grup otel işletmelerinin inovasyon ile ilgili merkezlerinde departmanlarının var olması gösterilebilir. Diğer taraftan araştırma kapsamındaki 4 yıldızlı otel işletmelerinin de inovasyon faaliyeti düzeylerinin 3 yıldızlı otellerden yüksek olduğu tespit edilmiştir. Bu durum beklenen bir sonuçtur ve daha önce yapılmış çalışmalarca desteklenmektedir. Çünkü 4 yıldızlı otel işletmeleri nispeten daha fazla çalışana sahiplerdir. Ayrıca 3 yıldızlı otel işletmelerine göre daha büyük olan 4 yıldızlı otel işletmelerinin daha fazla kaynağa sahip olduğu bu nedenle inovasyon faaliyetleri açısından daha avantajlı oldukları 
söylenebilir. Son olarak bünyesinde inovasyon ile ilgili yönetici bulunduran otel işletmelerinin inovasyon faaliyetleri düzeylerinin, inovasyon ile ilgili yöneticisi olmayan otel işletmelerine göre daha yüksek olduğu tespit edilmiştir. Daha önce yapılmış olan çalışmalar ve literatür bu sonucu desteklemektedir. İnovasyon ile ilgili yönetici bulunması otel işletmelerinin inovasyon faaliyetleri üzerinde olumlu etkiler yapacaktır. Çünkü inovasyon sürecine ilişkin bilgilendirilmelerin ve yönlendirmelerin yapılması işletmenin inovasyon potansiyelini olumlu etkileyebilir.

Araştırma sonuçlarında görüldüğü üzere inovasyon faaliyetlerini etkileyen birçok değişken bulunmaktadır. Burada en önemli unsur otel işletmelerinin kendi ölçeklerine uygun olarak inovasyon faaliyetlerine yönelmeleridir. Otel işletmelerinin inovasyon performanslarının artırılabilmesine ilişkin, inovasyon faaliyetlerine bütçe ayrılması, çalışanlara inovasyon ile ilgili eğitimlerin verilmesi, mümkünse inovasyon ile ilgili departman kurulması veya yönetici istihdam edilmesi ve işletmenin öğrenen organizasyona dönüştürülerek inovasyonun örgüt kültürünün bir parçası haline getirilmesi önerilebilir. İnovasyonun örgüt kültürünün parçası haline getirilmesi sürecinde, örgüt içerisinde inovasyona odaklanılması, örgüt içerisinde inovasyon alanında işbirliğinin geliştirilmesi, inovasyon faaliyetleri gerçekleştirilecekse inovasyon faaliyetleri içerisinde yer alabilecek nitelikte çalışanların istihdam edilmesi, inovasyon faaliyetlerini teşvik edici uygulamalara yer verilmesi ve inovasyon faaliyetlerinin sonuçlarının ölçülmesi gerekir (Kirsner, 2020). Ayrıca otel işletmelerinin inovasyon faaliyetleri konusunda lider işletmeleri beklemeden hızlı hareket etmeleri, etkin veri sistemi kurmaları, veri odaklı karar vermeleri, üst yönetimin inovasyon faaliyetlerine destek vermesi ve işletmenin müşteri odaklı olması gereklidir (Çağlayan, 2020). Otel işletmelerinde bilgi yönetimi faaliyetlerinin inovasyon faaliyetleri üzerinde olumlu etkisi bulunmaktadır (Kutanis ve Mesci, 2013: 367; Abdi vd., 2015: 153). Bu nedenle otel işletmelerinde bilgi yönetimi faaliyetlerine önem verilmelidir. Otel işletmelerinde çevre ve işletme analizleri sonucunda elde edilen bilginin sinıflandırılması, analiz edilmesi ve raporlanması için süreçlerin oluşturulması ve elde edilen bilginin işletme içerisinde dağıtımının gerçekleştirilmesi inovasyon faaliyetlerini olumlu yönde etkileyecektir. Diğer taraftan inovasyonu destekleyecek iş uygulamalarının işletme içerisinde hayat geçirilmesi inovasyon faaliyetleri üzerinde etkiye sahiptir (Crossan ve Apaydin, 2010: 1179). İnovasyon faaliyetlerini destekleyecek iş uygulamalarının geliştirilmesi ve bu kapsamda çalışanların inovasyon odaklı örgüt tasarımı içerisinde çalışmaları, çalışanların inovasyon faaliyetleri içerisinde yer almalarını kolaylaştıracaktır (Özşeker vd., 2018: 140-143). Böylelikle otel işletmelerinin inovasyon faaliyetleri performansları artacaktır. $\mathrm{Bu}$ nedenle inovasyon faaliyetlerini destekleyecek iş uygulamalarına önem verilmelidir. Ayrıca inovasyon faaliyetlerinin geliştirilmesi ve işletmelerin dolayısıyla ülkelerin daha fazla rekabet avantajı elde edebilmeleri için kamu sektörüne önemli görevler düşmektedir. Birçoğu aile işletmesi olan ve kobi olarak hizmet sunan otel işletmelerinin inovasyon faaliyetleri için yeterli insan ve finans kaynağı bulmaları çok zordur. Bu nedenle kamu kurumlarının inovasyon faaliyetleri konusunda otel işletmelerine liderlik yapması gerekir. Kamu kurumlarının öncülüğünde bölgesel veya ulusal inovasyon ajanslarının kurulması ve otel işletmelerine destek olmaları inovasyon faaliyetleri açısından önemlidir. İnovasyon faaliyetlerinin istenilen düzeye çıması otel işletmelerinin gelirini artıracaktır. Dolayısıyla otel işletmelerinin gelirlerine bağlı olarak ülkenin turizm gelirleri artacaktır (Şimşek, 2019: 107; Divisekera ve Nguyen, 2018: 157; HernandezPerlines vd. 2019: 220). Turizm geliri açısından istenilen düzeyde olmayan Türkiye için inovasyon faaliyetlerinde liderlik yapacak bir yapının oluşturulması önemli katkılar sağlayabilir.

Çalışma Sivas'ta faaliyet gösteren turizm işletme belgeli otel işletmelerinin inovasyon faaliyetlerine ilişkin yapılan ilk çalışma olması nedeni ile özgündür. Ancak daha sonra yapılacak çalışmalarda bu çalışma sonucunda ortaya çıkan farklılıkların kaynağı olarak görülen 
değişkenlerin, inovasyon faaliyetleri üzerindeki etkileri ölçülebilir. Böylelikle farklılıkların altında yatan sebeplere ilişkin değerlendirmelerin doğruluğu ve geçerliliği tespit edilmiş olur.

\section{KAYNAKÇA}

Abdi, K. and Senin, A.A. (2015). The Impact of Knowledge Management on Organizational Innovation: An Empirical Study, Asian Social Science, 11(23), 153-168.

Abernathy, W. J. and K. B. Clark (1985). Innovation: Mapping the Winds of Creative Destruction. Research Policy, 14(1), 3-22.

Akın, Ö. ve Reyhanoğlu, M. (2014). İşletme Büyüklükleri Bağlamında Türkiye'nin İnovasyon Portresi (2002-2008 Dönemi), Dokuz Eylül Üniversitesi Sosyal Bilimler Enstitüsü Dergisi, 16(1), 2351.

Bağıran Özşeker, D., Kurgun, H. ve Kurgun O. A. (2018). Otel İşletmelerinde İş Modeli İnovasyonunda Stratejik Bir Yaklaşım Olarak İnovasyon Radarı: Swissotel Büyük Efes İzmir Örnek Olay Çalışması, Journal of Tourism and Gastronomy Studies, 6(3), 133-170.

Bucak, T. ve Özarslan, H. (2016). Otel İşletmelerinde Hizmet Kalitesi ile Misafir Memnuniyeti Arasındaki İlişki (Çanakkale İli Merkezindeki 4 ve 5 Yıldızlı Oteller Örneği), Sosyal ve Beşeri Bilimler Araştırmaları Dergisi, 17(36), 1-28.

Büyüköztürk, Ş. (2010). Sosyal Bilimler İçin Veri Analizi El Kitabı. (12. Basım). Ankara: Pegem Yayınları.

Can, A. (2019). SPSS ile Bilimsel Araştırma Sürecinde Nicel Veri Analizi. (7.Basım). Ankara: Pegem Akademi.

Crossan M. M. and Apaydin, M. (2010). A Multi-Dimensional Framework of Organizational Innovation: A Systematic Review of the Literature, Journal of Management Studies, 47(7), 1153-1191.

Çağlayan, Y. (2020). Şirketleri İnovasyon Lideri Yapan Beş Özellik, Harvard Business Review, Cilt: 1. https://hbrturkiye.com/blog/sirketleri-inovasyon-lideri-yapan-bes-ozellik. Erişim tarihi: 22.06.2020.

Çetin, K. ve Gedik, H. (2017). İşletmelerde İnovasyona Etki Eden Faktörler: Karaman İli Örneği. Uluslararası Yönetim İktisat ve İşletme Dergisi, ICMEB17 Özel Sayısı, 160- 172.

Divisekera, S. and Nguyen, V. K. (2018). Determinants of Innovation in Tourism Evidence from Australia. Tourism Management, 67(3), 157-167.

Drucker, P. F. (1998). The Discipline of Innovation, Harward Business Rewiew, NovemberDecember, 6, 3-8.

Drucker, P. (1985). Innovation and Entrepreneurship. New York: Harper \& Row

Hendry, A., Leon, F. M. and Kurniawati, B. (2019). Antecedents and Consequences of Organizational Innovation: Perspectives of 2-Star and 3-Star Hotel Employees in Badung Regency, Bali, Review of Integrative Business and Economics Research, 9(2), 189-208.

Hernández-Perlines, F., Ariza-Montes, A., Han H. and Law, R. (2019). Innovative Capacity, Quality Certification and Performance in the Hotel Sector, International Journal of Hospitality Management, 82(3), 220-230.

Hjalager, A. M. (2002). Repairing Innovation Defectiveness in Tourism, Tourism Management, 5(23), 465-474. 
https://sozluk.gov.tr/, Erişim tarihi: 04.02.2020.

Jones, Gareth R. (2017). Örgüt Kuramı, Örgüt Tasarımı ve Örgütsel Değişim, (Çevirenler: A. A. Gülova, L. O. Ataç ve D. Dirik), Ankara: Gazi Kitabevi.

Kallmuenzer, A. (2018). Exploring Drives of Innovation in Hospitality Family Firms. International Journal of Contemporary Hospitality Management, 30(03), 1978-1995.

Karacaoğlu, K. ve Sözbilen, G. (2013). Kurumsallaşmanın Konaklama İşletmelerinin Kurumsal Girişimcilik Düzeyleri Üzerine Etkisi: Nevşehir İlinde Bir Uygulama. Anatolia: Turizm Araştırmaları Dergisi, 24(1), 41 - 56.

Karagöz, Y. (2017). Bilimsel Araştırma ve Yayın Etiği, Ankara: Nobel Akademik Yayıncılık.

Kılıç, R. ve Keklik, B. (2012). Kobi'lerde Genel Firma Özelliklerinin İnovasyon Uygulamalarına Etkisi: Balıkesir İlinde Bir Araştırma, Erciyes Üniversitesi İktisadi ve İdari Bilimler Fakültesi Dergisi, 39(1), 93-118.

Kirsner, S. (2019). What Companies That are Good at Innovation Get Right, Harvard Business Review, Cilt: 11. https://hbr.org/2019/11/what-companies-that-are-good-at-innovation-get-right. Erişim Tarihi: 22.06.2020.

Kogabayev, T. and A. Maziliauskas. (2017). The Definition and Classification of Innovation, Holistica, 8(1), 59-72. Doi:10.1515/hjbpa-2017-0005

Kotler, P. ve M. Kotler. (2016). Küresel Pazarda Büyümenin 8 Yolu, İstanbul: MediaCat Yayınları.

Kutanis, R. ve Mesci, M. (2013). A Research Aimed at Determining the Mediating Eff ect of IntraOrganizational Dynamics in The Relationship Between Information Management and Innovation. Ege Academic Review, 13 (3), 367-381.

Monteiro I. P. and F. C. Sousa. (2011). Understanding Innovation in Hospitality Through the Words of Innovative Managers, I - International Conference On Tourism \& Management Studies, Algarve.

Namjooyan, S. (2015). Exploring the Barriers to Innovation within North Cyprus Hotels, Eastern Mediterranean University, Master of Science in Tourism Management, Unpublished Master Thesis, Gazimağusa, North Cyprus.

OECD/Eurostat, (2019). Oslo Manual 2018: Guidelines for Collecting, Reporting and Using Data on Innovation, 4. Bask1, The Measurement of Scientific, Technological and Innovation Activities, OECD Publishing, Paris/Eurostat, Luxembourg, https://doi.org/10.1787/9789264304604-en.

Orfila-Sintas, Francina and Mattsson, J. (2009). Innovation Behavior in The Hotel Industry, Omega, 37(2), $380-394$

Özen, Kutanis, R. ve Mesci, M. (2013). Bilgi Yönetimi ile Yenilik Arasındaki İlişkide Örgüt İçi Dinamiklerin Ara Değişkenlik Etkisini Belirlemeye Yönelik Bir Araştırma. Ege Akademik Bakış, 13(3), 367-381.

Özkoç, A. G. ve Kemer, E. (2017). Konaklama İşletmelerinde Kurumsallaşmanın Örgütsel Yenilik Açısından Stratejik Rolü. Gaziantep University Journal of Social Sciences, 16(2), 568-578.

Pardo, P., M. Cooper, Steiner, D. and Claster, W. B. (2013). The Impact of Technology Innovativeness on Four- and Five-Star Hotels in Switzerland. Journal of Hospitality \& Tourism, ISSN No- 0972-7787. 11(2), 1-18.

Rothwell, R. and Gardiner, P. (2007). The Strategic Management of Re-Innovation. RED Management. 19, 147-160. 
Schumpeter, J. (1934). Capitalism, Socialism and Democracy. New York: Harper \& Row.

Şimşek, H. (2019). Pazar Yönlülük ve İnovasyonun Performans Üzerindeki Etkisi: Antalya' da Bir Araştırma, Girişimcilik Inovasyon ve Pazarlama Araştırmaları Dergisi, 6(3),107-128.

Tekin, Y. ve Durna, U. (2012). Otel İşletmelerinde Yenilik Yönetimi Uygulamaları Alanya' da Beş ve Dört Yıldızlı Otel İşletmelerinde Bir Araştırma. Uluslararası Alanya İşletme Fakültesi Dergisi, 4(3), 93-110.

Ünal, A. ve Kılınç, İ. (2016). İnovasyon Yönetimi, (Editör) ÇATI K.: Girişimcilik ve İnovasyon Yönetimi içinde (s.98-117), Ankara: Nobel Akademik Yayıncıllk.

Zengin, B. ve Dursun, C. (2017). Otel İşletmelerinde Uygulanan İnovatif Faaliyetlerin Rekabet Avantajı Üzerine Etkileri: Doğu Marmara Örneği, Turizm ve Araştırma Dergisi, 6(2), 38-58. 